\title{
PENINGKATAN PRODUKTIVITAS TERNAK UNGGAS MELALUI PEMBERIAN PAKAN FERMENTASI DI DESA APITAIK KABUPATEN LOMBOK TIMUR
}

\section{IMPROVEMENT OF POULTRY LIVESTOCK PRODUCTIVITY THROUGH FERMENTATION FEEDING IN APITAIK VILLAGE OF EAST LOMBOK DISTRICT}

\author{
Dwi K. Purnamasari ${ }^{*}$, Syamsuhaidi, Erwan, K.G. Wiryawan, Sumiati, Pardi, Tjok S. Binetra \\ Program Studi Peternakan, Universitas Mataram \\ Jalan Majapahit, Nomor 62, Kota Mataram, Provinsi NTB, 83115 \\ ${ }^{*}$ Alamat korespondensi : emmadkp@yahoo.com \\ (Tanggal Submission: 11 Maret 2020, Tanggal Accepted: 14 April 2020 )
}

\begin{abstract}
ABSTRAK
Desa Apitaik merupakan desa yang memiliki potensi dalam bidang peternakan, dimana ketersediaan bahan pakan lokal yang berasal dari limbah pertanian dan perikanan cukup besar. Namun saat ini peternak belum maksimal memanfaatkan limbah pertanian dan perikanan, dikarenakan kurangnya pengetahuan dalam pengolahan limbah menjadi pakan ternak yang berkualitas. Kegiatan pengabdian ini bertujuan untuk menyampaikan informasi dan pengetahuan dalam rangka meningkatkan produktifitas dan kesehatan ternak unggas melalui pemberian pakan fermentasi dan pemanfaatan fermentor sebagai probiotik dalam air minum. Tahapan kegiatan yaitu: 1). Penyuluhan tentang sistem peternakan unggas, berbagai macam bahan pakan lokal, manfaat serta penggunaannya. 2). Pengenalan dan demonstrasi metode pengolahan bahan pakan dengan menggunakan fermentor dan penggunaan fermentor sebagai probiotik dalam air minum. 3). Diskusi menggali potensi, permasalahan, dan mencari solusi secara bersama. Selama kegiatan pengabdian, peserta menunjukkan semangat yang tinggi untuk berusaha di bidang peternakan khususnya ayam ras petelur. Nampak dari jumlah kehadiran peternak yang tinggi (31 orang), dan keaktifan peternak dalam diskusi serta lamanya diskusi ( \pm 4 jam), serta peternak bersemangat untuk mencoba fermentor dalam pengolahan pakan. Peternak berkomitmen untuk meningkatkan produktifitas ternak dan kesehatan ternak dengan memanfaatkan limbah pertanian hasil fermentasi.
\end{abstract}

Kata kunci: penyuluhan, demonstrasi, fermentasi, pakan, unggas

\section{PENDAHULUAN}

Pengembangan agribisnis perunggasan di Indonesia saat ini telah berkembang relatif cukup cepat dan mampu memenuhi kebutuhan dalam negeri dan pada beberapa periode juga telah dapat melakukan ekspor (Ilham, 2015) serta telah terbukti bahwa agribisnis perunggasan merupakan bisnis pertanian yang mampu mandiri dan ikut dalam menyukseskan program pemerintah, yaitu membuka lapangan pekerjaan, menumbuhkan sentra-sentra usaha baru, merangsang produksi pertanian lainnya dan menciptakan pendapatan masyarakat hingga ke desa-desa (Utoyo, 2017).

Desa Apitaik adalah salah satu desa di Kecamatan Pringgabaya Kabupaten Lombok Timur Propinsi NTB saat ini tengah mengembangkan usaha perunggasan ayam pedaging dan ayam petelur. Masyarakat desa Apitaik melihat bahwa potensi daerahnya cukup besar untuk mengembangkan industri perunggasan, di mana 
bahan pakan lokal yang berasal dari limbah-limbah pertanian dan perikanan tersedia cukup dan terdapat pula pabrik pakan mini yang menyediakan pakan-pakan komplit dan konsentrat untuk unggas. Namun saat ini peternak mulai mengurangi pemanfaatan sepenuhnya pakan-pakan komersial untuk menekan biaya produksi yaitu dengan memanfaatkan bahan-bahan pakan lokal yang merupakan limbah pertanian dan limbah perikanan.

Penggunaan limbah pertanian dan perikanan sebagai pakan unggas telah banyak diteliti. Purnamasari, dkk. (2015) telah meneliti penggunaan limbah rajungan yang memiliki potensi yang tinggi sebagai pakan itik petelur, dimana kandungan protein kasar yang tinggi (32.95\%) dan kalsium mencapai (22.93\%), berperan penting dalam meningkatkan kualitas eksternal telur (tebal kerabang $=0.48 \pm 0.01 \mathrm{~mm}$ ) pada pemberian $4 \%$ serta meningkatkan score warna kuning telur $(13.30 \pm 0.45$ RCF $)$ pada pemberian $8 \%$ limbah rajungan. Penggunaan ikan sapu sapu segar sebagai pakan itik petelur hingga $20 \%$ memberikan respon positif terhadap terjadinya peningkatan produksi telur sebesar $21.7 \%$ dibandingkan bila diberikan dalam bentuk kering dan meningkatkan score warna kuning telur (9.84 RCF) secara signifikan (Indarsih, et al., 2016).

Namun demikian, penggunaan bahan pakan lokal limbah pertanian memiliki kendala yaitu rendahnya kandungan protein dan tingginya kadar serat kasar, sehingga selama ini peternak menggunakan masih dalam jumlah yang sedikit karena keterbatasan unggas dalam mencerna bahan pakan berserat. Untuk itu perlu diberikan tambahan informasi dan sosialisasi tehnologi pada masyarakat di Desa Apitaik melalui pengolahan bahan pakan berserat melalui proses fermentasi dengan menggunakan berbagai fermentor dalam rangka meningkatkan kandungan protein dan menurunkan kandungan serat kasar bahan pakan, sehingga bahan pakan limbah industri pertanian dapat dimanfaatkan secara maksimal.

Fermentasi adalah proses pengubahan suatu senyawa komplek menjadi senyawa yang lebih sederhana menggunakan bantuan mikroorganisme baik dalam kondisi aerobik maupun anaerobik. Berdasarkan kadar substrat dan air, fermentasi dibagi menjadi dua tipe, yaitu fermentasi kultur terendam (kadar air sekitar 90\%) dan fermentasi substrat padat (kadar air $40-75 \%$ ).
Proses fermentasi hasil samping tanaman perkebunan (bungkil inti sawit dan kelapa), tanaman pangan (dedak padi dan polard gandum), serta industri pertanian (kulit singkong, onggok, dari pabrik tapioca) untuk bahan pakan umumnya dilakukan dengan fermentasi substrat padat. Fermentasi substrat padat dinilai lebih baik karena volume proses fermentasi lebih rendah dibanding kultur terendam yang mengandung kadar air lebih tinggi (Stephanie dan Purwadaria, T., 2013).

Pemberian pakan pada unggas dengan menggunakan bahan pakan yang terlebih dahulu di fermentasi telah banyak diteliti dan dilakukan. Praditya (2015) telah menciptakan pakan ayam kampung dengan menggunakan tepung tempe yang merupakan hasil fermentasi kedele kaya akan kandungan asam amino, dan ternyata mampu menghasilkan ayam dengan daging yang lebih sehat karena rendah lemak dengan kandungan protein yang lebih tinggi tanpa residu antibiotik. Lebih lanjut dinyatakan bahwa proses fermentasi dalam tempe dapat menghasilkan enzim-enzim pencernaan seperti amylase, protease, dan lipase yang mengubah senyawa komplek menjadi senyawa yang sederhana. Zaman, dkk. (2013) melakukan penelitian pengolahan tanaman gulma yaitu kiambang yang difermentasi dengan ragi tempe pada ayam pedaging mampu menurunkan angka konversi pakan dan angka konversi pakan terbaik yang dihasilkan adalah $0.8825 \pm 0.09$.

Oladunjoye et al., (2010) meneliti pengaruh substitusi bungkil jagung dengan tepung kulit singkong kering matahari dan yang direndam dengan air abu kayu pada ayam petelur, menghasilkan tidak ada perbedaan yang nyata pertumbuhan bobot badan dan konsumsi pakan pada substitusi $50-80 \%$, namun pada substitusi $50 \%$ produksi telur dan konversi pakan yang paling optimum. Pada profil kualitas telur hampir tidak terdapat perbedaan, kecuali warna kuning telur serta kadar kolesterol lebih rendah pada perlakuan substitusi. Fermentasi kulit singkong mampu menurunkan kadar sianogenik kulit singkong dan menghasilkan enzim lignoselulosa yang mampu menurunkan kadar lignin sampai 52,6\% (Tijani et al., 2012).

Proses fermentasi juga dapat menjadi solusi penyimpanan bahan pakan dalam waktu yang lebih lama selain dapat meningkatkan kualitas bahan pakan. Dedak padi merupakan salah satu contoh bahan pakan yang ketersediaannya 
sepanjang tahun berfluktuasi, yang mana ketika musim panen ketersediaannya melimpah, namun sebaliknya ketika musim kemarau ketersediaannya berkurang. Selain itu dedak padi tidak dapat disimpan dalam jangka waktu yang lama, disebabkan karena adanya aktivitas enzim yang dapat menyebabkan kerusakan atau ketengikan pada komponen minyak atau lemak yang ada dalam dedak padi. Tehnologi dedak padi fermentasi dapat meningkatkan kandungan gizi, memperpanjang waktu simpan dan menurunkan kandungan asam fitat yang ada pada dedak padi sehingga penggunaannya dapat maksimal.

Tehnologi fermentasi adalah tehnologi yang mudah untuk dilakukan oleh peternak dengan biaya yang murah namun dapat meningkatkan kualitas bahan pakan dan memperpanjang waktu simpan sehingga dapat mengatasi kesulitan pakan pada musim kemarau dan dapat menekan biaya produksi usaha. Dengan demikian kegiatan pengabdian ini penting dilakukan dengan tujuan memberikan informasi dan pengetahuan kepada peternak dan masyarakat desa Apitaik tentang bahan-bahan pakan lokal yang bersumber dari limbah pertanian dan perikanan yang dapat dimanfaatkan sebagai pakan ternak dengan terlebih dahulu dilakukan pengolahan dengan teknologi fermentasi untuk meningkatkan kualitas bahan pakan.

\section{METODE KEGIATAN}

Kegiatan pengabdian masyarakat ini dilaksanakan dalam bentuk diskusi bersama-sama mencari penyebab permasalahan yang timbul dan memecahkan permasalahan tersebut dengan solusi yang tepat. Melatih peternak dalam mengolah pakan dan mengembangkan usaha unggas secara berkelanjutan.

Berdasarkan pertimbangan di atas, pelatihan ini diadakan dengan program kerja sebagai berikut :

1). Pengenalan berbagai macam bahan pakan alternatif dan bahan pakan lokal, komposisi nutrisi dan manfaat serta penggunaannya bagi unggas.

2). Pengenalan metode pengolahan bahan pakan dengan menggunakan fermentor untuk meningkatkan kualitas bahan pakan. Kelompok peternak akan diberikan materi dan demonstrasi mengolah bahan pakan yang rendah kandungan protein dan tinggi kandungan serat kasar menjadi bahan pakan berkualitas dan mudah dicerna unggas dengan menggunakan fermentor, serta penggunaan fermentor dalam air minum.

3). Diskusi, membantu peternak dalam menggali potensi daerah yang ada, memecahkan permasalahan peternak secara bersama dan memberikan alternatif solusi-solusi yang bisa dikerjakan peternak.

\section{HASIL DAN PEMBAHASAN}

Kegiatan pengabdian pada masyarakat ini telah dilaksanakan melalui beberapa kegiatan sebagai berikut:

a. Penyampaian materi mengenai ayam ras petelur, faktor-faktor yang memepengaruhi produksi telur, managemen pemeliharaan, peluang dan dukungan sumber daya alam dalam penyediaan pakan unggas khususnya ayam ras petelur serta bagaimana usaha peternakan dilakukan secara berkelompok.

b. Penyampaian materi pemberian pakan unggas, pemanfaatan bahan pakan alternatif, pemanfaatan limbah-limbah pertanian dan perikanan sebagai pakan unggas, pengolahan limbah pertanian melalui teknologi fermentasi untuk meningkatkan kualitas bahan pakan menggunakan fermentor dan pemanfaatan fermentor dalam air minum untuk meningkatkan kesehatan ternak serta mengurangi bau yang ditimbulkan dari limbah peternakan.

c. Diskusi permasalahan-permasalahan yang dihadapi oleh peternak dan cara mengatasinya. Masalah yang berkembang dalam kegiatan diskusi yaitu:

- Masalah pemberian dosis dan cara pemberian probiotik

- Masalah perkandangan dan bau yang ditimbulkan

- Masalah produksi dan kualitas telur yang dihasilkan

- Masalah managemen dalam pemeliharaan

- Masalah penanganan limbah peternakan

- Masalah penyakit yang menyerang ternak unggas 


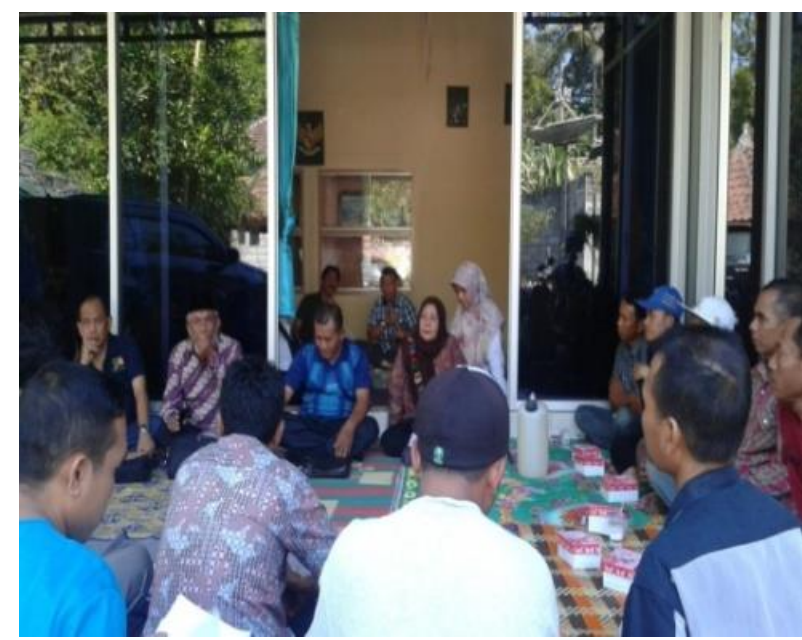

Gambar 1. Suasana kegiatan penyampaian materi dan diskusi

d. Memperkenalkan berbagai probiotik dan demostrasi cara penggunaannya pada beberapa jenis ternak dalam rangka meningkatkan produktifitas maupun dalam menekan bau yang ditimbulkan dari kotoran ternak (Gambar 2)

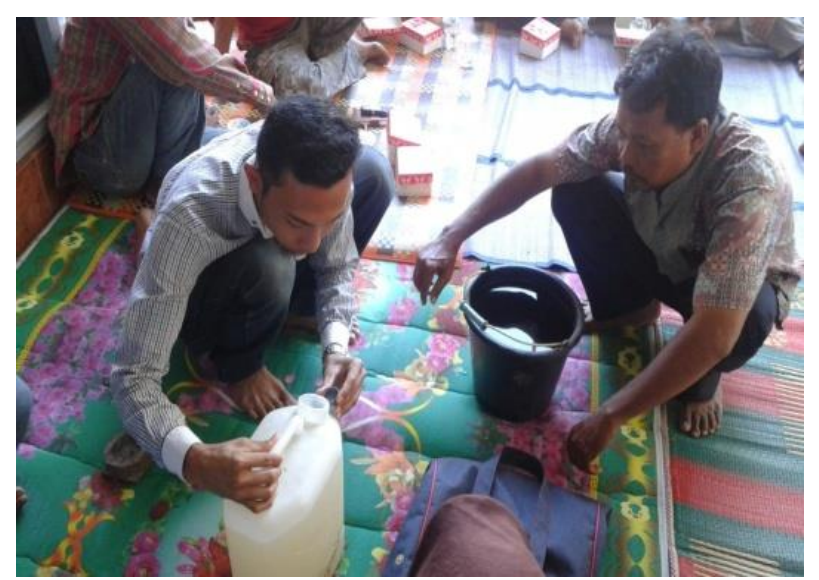

Gambar 2. Demonstrasi pemberian probiotik untuk berbagai jenis ternak

Berdasarkan hasil diskusi berbagai permasalahan yang muncul, maka ditetapkan beberapa solusi sebagai berikut:

1. Di desa Apitaik terdapat kelompok peternak ayam petelur yang terdiri dari 30 peternak, dengan masing masing peternak memiliki skala usaha rata-rata 3000 ekor ayam petelur. Usaha telah berlangsung selama 2 tahun dengan capaian produksi telur yang tinggi yaitu $90 \%$. Pakan yang diberikan berupa konsentrat (KLKS 36), dedak, dan jagung. Di desa tersebut juga terdapat pabrik pakan mini yang menyediakan segala kebutuhan peternak baik pakan, vitamin, mineral, obat-obatan dan perlengkapan perkandangan. Namun kelompok ini belum menjalankan organisasi kelompok secara professional, sehingga disarankan untuk:

a. Memubuat struktur keanggotaan kelompok.

b. Menyusun aturan tata tertib yang harus dipatuhi setiap anggota kelompok.

c. Mengadakan kas kelompok, melalui menabung 2 butir telur/perhari/peternak.

d. Membuat proposal bantuan ke instansiinstansi terkait dalam rangka pengembangan usaha, baik berupa pengadaan bibit ayam maupun pakan.

2. Produksi telur telah mencapai produksi yang maksimal (90\%) namun ukuran atau size telur kecil. Hal ini diduga adanya kompensasi dari tingginya jumlah produksi telur tapi tidak diiringi dengan kualitas yang maksimal, sehingga disarankan untuk memperhatikan jumlah pakan yang diberikan agar disesuaikan dengan kebutuhan dan memperhatikan faktor peremajaan ayam.

3. Masalah berikutnya yang dihadapi oleh peternak adalah masalah pakan, dimana pakan yang digunakan adalah pakan komersial yang diperoleh di Poultry Shop berupa konsentrat, dengan harga relatif mahal. Solusinya adalah dengan memanfaatkan bahan pakan alternatif yang ada disekitarnya yang dapat digunakan dan mengolahnya menjadi pakan yang berkualitas dengan proses fermentasi.

Berdasarkan analisis pengamatan selama kegiatan berlangsung hingga selesai kegiatan, maka dapat dideskripsikan sebagai berikut:

\section{Faktor Pendukung}

Masyarakat setempat mempunyai semangat yang sangat tinggi untuk berusaha di bidang peternakan khususnya ayam ras petelur, untuk memenuhi kebutuhan telur baik bagi untuk konsumsi masyarakat sendiri maupun untuk memenuhi kebutuhan restaurant - restauran di kabupaten Lombok Timur. Hal ini dapat dilihat dari jumlah kehadiran peternak yang tinggi (31 orang), dan banyaknya pertanyaan yang diajukan peternak serta lamanya diskusi ( \pm 4 jam) dan ditunjukkan dengan semangatnya peternak untuk mencoba tehnologi pemberian probiotik dan pengolahan pakan dengan menggunakan fermentor untuk 
meningkatkan produktifitas ternak dan menekan bau yang ditimbulkan dari kotoran ternak. Selain itu semangat yang tinggi ini juga dikarenakan di desa Apitaik terdapat pabrik pakan mini sehingga memudahkan peternak dalam mendapatkan pakan dan dapat menekan biaya produksi.

\section{Faktor Penghambat}

Faktor penghambat yang dirasa belum adanya dukungan pemerintah dalam membantu peternak dalam meningkatkan produktifitas usaha. Untuk itu pembuatan organisasi kelompok peternak yang professional amerupakan solusi yang terbaik.

\section{KESIMPULAN DAN SARAN}

\section{Kesimpulan}

Kegiatan pengabdian ini dirasakan manfaat oleh masyarakat dan menghasilkan komitmen untuk meningkatkan produktifitas dan kesehatan ternak dengan memanfaatkan limbah pertanian hasil fermentasi.

\section{Saran}

Kelompok peternak unggas yang ada perlu mendapat perhatian yang serius baik dari akademisi maupun dari instansi terkait dalam rangka pembinaan terhadap kelompok peternak unggas secara terus menerus/dan berkesinambungan.

\section{DAFTAR PUSTAKA}

Ilham, N., 2015. Kebijakan Pemerintah Terhadap Usaha Unggas Skala Kecil dan kesehatan
Lingkungan di Indonesia. Wartazoa Vol. 25 No. 2 Th. 2015 HIm 95 - 105.

Indarsih, B., Asnawi, D.K. Purnamasari, 2016. Sapusapu Fish (Hyposarcus pardalis) As a Single Protein Source For Laying Mojosari Ducks. J. Indonesian Trop. Anim. Agric: 41(3):117-24, September 2016.

Praditya, I.M., 2015. Ciptakan Ransum Pakan ayam Kampung. UGM Press : Jogjakarta.

Purnamasari, D.K., K.G. Wiryawan, Erwan, dan A. Paozan, 2015. Potensi Limbah Rajungan (Portunus pelagicus) sebagai pakan Itik Petelur. Jurnal Peternakan Sriwijaya/Vol. 4, No. 1, 2015, pp.11:19.

Stephanie, Purwadaria, T., 2013. Fermentasi substrat Padat Kulit singkong Sebagai Bahan Pakan Ternak Unggas. Wartazoa Vol. 23 No. $1 \mathrm{Th} .2013 \mathrm{~h} / \mathrm{m} 15$-22.

Tijani IDR, Jamal P., Alam MZ, Mirghani MES, 2012. Optimization of cassava peel medium to on enriched animal feed by the white rot fungi. Int Food Res. 19:427-432.

Utoyo, D.P., 2017. Tata Ulang Sistem Perunggasan Di Indonesia. Lokakarya Nasional Inovasi Tehnologi Dalam Mendukung Usaha Ternak Unggas Berdayasaing. Forum Masyarakat Perunggasan Indonesia.

Zaman, Q.,G. Suparno, dan D. Hariani, 2013). Pengaruh kiambang (Salvinia molesta) yang difermentasi dengan ragi tempe sebagai suplemen pakan terhadap peningkatan biomassa ayam pedaging. J. LenteraBio, vol. 2; No. 1, Januari 2013; 131-137. 